\title{
Damage and Survival of Bacteria during Freeze-Drying and during Storage over a Ten-Year Period
}

\author{
By A. P. harRison, Jun. and M. J. PELCZAR, Jun. \\ Department of Biology, Vanderbilt University, Nashville, Tennessee and \\ Department of Microbiology, University of Maryland, \\ College Park, Maryland, U.S.A.
}

(Received 15 June 1962)

\begin{abstract}
SUMMARY
Extrapolation from 10-year survival curves indicates that many lyophilized bacterial suspensions may be expected to yield viable organisms after centuries of storage, but that suspensions of Pseudomonadaceae may become sterile within one to several decades. The characters of Lactobacteriaceae and other bacteria appear unaltered as a result of lyophilization and storage for $\mathbf{5}$ years, but some Bacteroides isolates manifested apparently altered fermentation reactions under the same circumstances. Freezing bacteria in pellets is suggested as an alternative method of storage for those species which are particularly sensitive to lyophilization.
\end{abstract}

\section{INTRODUCTION}

For storage over long periods freeze-drying is a method often used for the maintenance of bacterial cultures. Although there are numerous reports about technique and conditions for freeze-drying, there is little quantitative information about viability and the stability of traits over a long period. Changes in interests and techniques within a given laboratory, as well as the personnel turnover through the years, distract from and render difficult long-term study. The present paper summarizes viability data on 12 species which have been stored in the dried state for 10 years.

\section{METHODS}

Methods of preparation of the desiccates. Escherichia coli 69L-15, Aerobacter aerogenes and Proteus vulgaris were cultivated at $35^{\circ}$ on a shaking apparatus for 18-24 hr. in $1 \%$ (w/v) yeast-extract broth. Acetobacter melanogenum American Type Culture Collection (ATCC) 9844, was cultivated at $27^{\circ}$ on the shaker for 2 days in the same medium containing $2 \%(\mathrm{w} / \mathrm{v})$ glucose. Micrococcus albus and a psychrophilic Pseudomonas sp. (isolated as a contaminant from a refrigerated room) were cultivated at $27^{\circ}$ on the shaker for 1 day in nutrient broth (Baltimore Biological Laboratories). Pseudomonas chlororaphis (from W. C. Haynes, North Regional Research Lab., U.S. Department of Agriculture) was cultivated at $27^{\circ}$ on the shaker for 1 day in a defined liquid medium developed by Kögl \& Postowsky (1930); Pseudomonas aeruginosa was cultivated under the same conditions except the temperature was $35^{\circ}$. Serratia marcescens ATCC 274 was cultivated at $27^{\circ}$ on the shaker for 1 day in a defined liquid medium devised by Bunting (1946). Vibrio costicolus (from N. E. 
Gibbons, National Research Council, Ottawa) was cultivated at $27^{\circ}$ on the shaker for 1 day in $1 \%(w / v)$ Trypticase (Baltimore Biological Laboratories) containing $2 \%(\mathrm{w} / \mathrm{v}) \mathrm{NaCl}$ (these ingredients were autoclaved separately). Lactobacillus bifidus $20-32$ and $L$. fermenti $69 \mathrm{~L}-3$ were grown at $37^{\circ}$ in static culture for 1 day in yeast-extract + Trypticase + glucose + calcium carbonate broth.

The media used for counting viable organisms were of the same composition as the corresponding liquid media which had been used to grow the organisms initially but contained $1.5 \%$ agar. Plates were incubated at the appropriate temperatures until development of good colonies (12 $\mathrm{hr}$. to several days, depending upon the particular organism).

Preparation of organisms for storage. Forty $\mathrm{ml}$. of a liquid culture were centrifuged, the supernatant fluid decanted, and the pellet of organisms taken up in $8 \mathrm{ml}$. of double-strength skim milk (prepared from the Difco dehydrated product). The suspension was well mixed and dispensed in $0.2 \mathrm{ml}$. portions into sterile cottonplugged ampoules $(10 \mathrm{~mm}$. diam. $\times 35 \mathrm{~mm}$.). All but two of these ampoules were placed at $-60^{\circ}$ in ethanol + solid $\mathrm{CO}_{2}$. Viable counts were made on the two unfrozen suspensions as follows. Each ampoule was carefully wiped with $95 \%$ ethanol, air dried, and aseptically placed into a sterile milk-dilution bottle containing $20 \mathrm{ml}$. $0.85 \% \mathrm{NaCl}$ and several marbles. The two bottles were vigorously shaken until the ampoules were well pulverized. From these 1/100 dilutions further serial dilutions were prepared and samples plated on appropriate nutrient agars.

Two of the frozen ampoules were thawed (at room temperature) and assayed as described above. The other ampoules were removed from the $-60^{\circ}$ bath and quickly placed in a jar (at room temperature) connected to a vacuum pump assembly. Drying from the frozen state was at $70-100 \mu \mathrm{Hg}$ and continued overnight. The ampoules were then removed from the jar, placed into phials (14 $\mathrm{mm}$. diam. $\times 60 \mathrm{~mm}$.), the ends packed with asbestos fibre, and the phials sealed under a pressure of 70-100 $\mu \mathrm{Hg}$. Two phials were opened immediately and the viable counts made. The other phials were stored at $8^{\circ}$ for various periods up to 10 years. The results will be expressed as total number of viable organisms/ampoule.

Several strains of a large $(1-2.5 \mu \times 5-20 \mu)$ Gram-negative obligate anaerobe, which had been isolated from faeces of turkeys (Harrison, 1949) and which will be referred to as Bacteroides sp. were handled somewhat differently. Growth was washed from agar slopes with double-strength skim milk and several tenths $\mathrm{ml}$. dispensed into ampoules $(7 \mathrm{~mm}$. diam. $\times 80 \mathrm{~mm}$. tubes with $11 \mathrm{~mm}$. diam. bulbs at the distal end). The suspensions were frozen at $-60^{\circ}$, dried directly from the freezing bath overnight at 70-100 $\mu \mathrm{Hg}$ (Model $103 \mathrm{PM}, \mathrm{F}$. J. Stokes Corp., Phila, Pa., U.S.A.), and the ampoules sealed without being disconnected from the manifold. Storage was at room temperature. Species of Lactobacteriaceae were lyophilized in the same way. Viable counts of these organisms were not made; it was noted simply whether the contents of an ampoule, when decanted into suitable broth, produced a growing culture. A detailed physiological study before and after (Stevens, 1956) storage of the lyophilized Bacteroides organisms was undertaken by the methods already outlined (Harrison \& Hansen, 1954). 


\section{RESULTS AND DISCUSSION}

Table 1 summarizes the viability data for 12 bacterial species. Freezing (with subsequent thawing) caused little, if any, decrease in count. On the other hand, subsequent manipulation (either drying or exposure to oxygen of the air after drying; Lion \& Bergmann, 1961) caused decrease in count, the response differing greatly among the species. Semilog-time plots of the data are useful to predict the longevity of the dried suspensions and to demonstrate the relative sensitivity of the different species. The death rate may decrease with time, thus a survival curve may

\section{Table 1. Viability of bacteria after freezing, drying, and storage in the dried state*}

(All assays represent the total number of viable organisms by colony count in the ampoule.)

\begin{tabular}{|c|c|c|c|c|c|c|c|c|}
\hline \multirow[b]{2}{*}{ Species } & \multirow[b]{2}{*}{$\begin{array}{l}\text { Initial } \\
\text { count }\end{array}$} & \multirow{2}{*}{$\begin{array}{c}\text { After } \\
\text { freezing }\end{array}$} & \multirow[b]{2}{*}{$\begin{array}{c}\text { After } \\
\text { drying }\end{array}$} & \multicolumn{5}{|c|}{ After storage for } \\
\hline & & & & 1 week & 4 weeks & 8 weeks & & 10 years \\
\hline Escherichia coli & $\begin{array}{l}8 \cdot 2 \times 10^{9} \\
9 \cdot 4 \times 10^{9}\end{array}$ & $\begin{array}{l}9.2 \times 10^{9} \\
8.6 \times 10^{9}\end{array}$ & $\begin{array}{l}5.6 \times 10^{9} \\
9.8 \times 10^{9}\end{array}$ & & & & & \\
\hline Vibrio costicolus & $\begin{array}{l}4.0 \times 10^{8} \\
2.2 \times 10^{8}\end{array}$ & $\begin{array}{l}3.8 \times 10^{8} \\
3.8 \times 10^{8}\end{array}$ & - & & $\begin{array}{l}1.4 \times 10^{4} \\
8.6 \times 10^{3}\end{array}$ & & & \\
\hline $\begin{array}{l}\text { Lactobacillus } \\
\text { bifidus }\end{array}$ & $\begin{array}{l}2.0 \times 10^{8} \\
4.8 \times 10^{8}\end{array}$ & $\begin{array}{l}3.4 \times 10^{8} \\
2 \cdot 8 \times 10^{8}\end{array}$ & $\begin{array}{l}3.6 \times 10^{8} \\
2.6 \times 10^{8}\end{array}$ & & & & & \\
\hline L. fermenti & $\begin{array}{l}5.6 \times 10^{8} \\
8 \cdot 0 \times 10^{8}\end{array}$ & $\begin{array}{l}6.0 \times 10^{8} \\
5.2 \times 10^{8}\end{array}$ & $\begin{array}{l}2.4 \times 10^{8} \\
3.0 \times 10^{8}\end{array}$ & $\begin{array}{l}2.0 \times 10^{8} \\
2.4 \times 10^{8}\end{array}$ & & & & \\
\hline $\begin{array}{l}\text { Acetobacter } \\
\text { melanogenum }\end{array}$ & $\begin{array}{l}8 \cdot 2 \times 10^{8} \\
5 \cdot 8 \times 10^{8}\end{array}$ & $\begin{array}{l}7 \cdot 6 \times 10^{8} \\
7 \cdot 2 \times 10^{8}\end{array}$ & & & & & - & \\
\hline $\begin{array}{c}\text { Aerobacter } \\
\text { aerogenes }\end{array}$ & $\begin{array}{l}4.4 \times 10^{9} \\
4.8 \times 10^{9}\end{array}$ & $\begin{array}{l}4 \cdot 4 \times 10^{9} \\
5 \cdot 0 \times 10^{9}\end{array}$ & $\begin{array}{l}2.0 \times 10^{9} \\
2.6 \times 10^{9}\end{array}$ & & & & & \\
\hline $\begin{array}{l}\text { Pseudomonas } \\
\text { sp. }\end{array}$ & $\begin{array}{l}5 \cdot 6 \times 10^{9} \\
7 \cdot 8 \times 10^{9}\end{array}$ & $\begin{array}{l}7.6 \times 10^{9} \\
1.1 \times 10^{10}\end{array}$ & $\begin{array}{l}1.1 \times 10^{9} \\
1.3 \times 10^{9}\end{array}$ & $\begin{array}{l}1.3 \times 10^{9} \\
3.2 \times 10^{8}\end{array}$ & & & & \\
\hline P. aeruginosa & $4 \cdot \overline{4} \times 10^{9}$ & $\begin{array}{l}3.0 \times 10^{9} \\
2.2 \times 10^{9}\end{array}$ & $\begin{array}{l}3.2 \times 10^{8} \\
6.8 \times 10^{7}\end{array}$ & $\begin{array}{l}1.0 \times 10^{8} \\
1.0 \times 10^{7}\end{array}$ & & & - & \\
\hline P. chlororaphis & $\begin{array}{l}8.8 \times 10^{9} \\
1.0 \times 10^{10}\end{array}$ & $\begin{array}{l}8.2 \times 10^{9} \\
1.0 \times 10^{10}\end{array}$ & $\begin{array}{l}2.0 \times 10^{6} \\
3.2 \times 10^{7}\end{array}$ & - & & $\begin{array}{l}1.0 \times 10^{5} \\
1.9 \times 10^{5}\end{array}$ & $\begin{array}{l}6.6 \times 10^{5} \\
6.0 \times 10^{5}\end{array}$ & \\
\hline Proteus vulgaris & $\begin{array}{l}3.2 \times 10^{9} \\
3.0 \times 10^{9}\end{array}$ & $\begin{array}{l}2 \cdot 8 \times 10^{9} \\
3 \cdot 2 \times 10^{9}\end{array}$ & $\begin{array}{l}6 \cdot 8 \times 10^{7} \\
6 \cdot 0 \times 10^{7}\end{array}$ & $\begin{array}{l}5 \cdot 4 \times 10^{7} \\
5 \cdot 0 \times 10^{7}\end{array}$ & $\begin{array}{l}9 \cdot 2 \times 10^{6} \\
3.6 \times 10^{5}\end{array}$ & $\begin{array}{l}9.8 \times 10^{6} \\
1.0 \times 10^{7}\end{array}$ & - & \\
\hline $\begin{array}{l}\text { Serratia } \\
\text { marcescens }\end{array}$ & $\begin{array}{l}9 \cdot 4 \times 10^{8} \\
1 \cdot 0 \times 10^{9}\end{array}$ & $\begin{array}{l}8.8 \times 10^{8} \\
8.4 \times 10^{8}\end{array}$ & $\begin{array}{l}1.8 \times 10^{8} \\
1.6 \times 10^{8}\end{array}$ & $\begin{array}{l}8.8 \times 10^{7} \\
3.4 \times 10^{8}\end{array}$ & $\begin{array}{l}3.8 \times 10^{8} \\
1.2 \times 10^{8}\end{array}$ & $\begin{array}{l}1.4 \times 10^{8} \\
9 \cdot 8 \times 10^{7}\end{array}$ & $\begin{array}{l}2 \cdot 2 \times 10^{7} \\
7 \cdot 4 \times 10^{6}\end{array}$ & $\begin{array}{l}2 \cdot 2 \times 10^{7} \\
7 \cdot 4 \times 10^{7}\end{array}$ \\
\hline $\begin{array}{l}\text { Micrococcu } \\
\text { albus }\end{array}$ & $\begin{array}{l}4.8 \times 10^{9} \\
4.2 \times 10^{9}\end{array}$ & $\begin{array}{l}4.2 \times 10^{9} \\
4.8 \times 10^{9}\end{array}$ & $\begin{array}{l}2.6 \times 10^{9} \\
2.6 \times 10^{9}\end{array}$ & $\begin{array}{l}2.8 \times 10^{9} \\
1.8 \times 10^{9}\end{array}$ & $\begin{array}{l}2.8 \times 10^{9} \\
2.0 \times 10^{9}\end{array}$ & $\begin{array}{l}4.4 \times 10^{8} \\
1.4 \times 10^{9}\end{array}$ & - & $\begin{array}{l}1.3 \times 10^{9} \\
7.8 \times 10^{8}\end{array}$ \\
\hline
\end{tabular}

* Suspended in double-strength skim milk, frozen at $-60^{\circ}$, dried at $70-100 \mu \mathrm{Hg}$ and stored at $8^{\circ}$.

have a continuously decreasing slope. Upon extrapolation from the 12-week (or 8-week) and 10-year points we find that the ampoules containing the Vibrios and Acetobacters can be expected to become sterile within several decades, whereas (assuming constant death rate) most ampoules can be expected to contain some viable organisms after centuries of storage. (Of course, the longevity will depend upon the number of organisms initially present.) We can compare sensitivities by means of death rates. Thus, the numbers of years required to cause a mere ten-fold 
decrease in count are, respectively, 100 (for Escherichia coli), 3, 9, 40, 1, 40, 25, 5, 25, 35, 17, and many 100's (for Micrococcus albus). There appears little correlation with phylogeny, although members of Pseudomonadaceae (Acetobacter, Vibrio, Pseudomonas) are among the most sensitive. (Vibrio cholera also does not tolerate lyophilization well according to Rhodes \& Fisher, 1950; Stamp, 1947.) Appreciable variation in sensitivity occurs among different genera of Enterobacteriaceae.

Although it may be possible to retain viability of a suspension in the dried state for very long periods, it might be unwise to allow too great a decrease in count to take place. Unequal selection of different genotypes within the population might occur, thus the mass characters of the culture might be altered. Indeed, the reason

Table 2. Final $\mathrm{pH}$ values of broth cultures of two Bacteroides strains before lyophilization and after lyophilization and storage at room temperature for 5 years*

\begin{tabular}{|c|c|c|c|c|}
\hline \multirow[b]{2}{*}{ Substrate } & \multicolumn{2}{|c|}{ Strain 21-28 } & \multicolumn{2}{|c|}{ Strain 28-30 } \\
\hline & Before $\dagger$ & After $\ddagger$ & Before $\dagger$ & After $\$$ \\
\hline Glycerol & $6 \cdot 9$ & $6 \cdot 6$ & $7 \cdot 0$ & $4 \cdot 7$ \\
\hline Xylose & $4 \cdot 8$ & $5 \cdot 1$ & $4 \cdot 7$ & $6 \cdot 4$ \\
\hline Arabinose & $4 \cdot 8$ & 6.5 & $4 \cdot 7$ & $6 \cdot 4$ \\
\hline Rhamnose & $6 \cdot 8$ & $6 \cdot 6$ & $6 \cdot 8$ & $6 \cdot 4$ \\
\hline Sorbitol & $5 \cdot 3$ & 6.7 & $5 \cdot 1$ & $6 \cdot 4$ \\
\hline Mannitol & $5 \cdot 5$ & $6 \cdot 6$ & $5 \cdot 3$ & 6.5 \\
\hline Inositol & $7 \cdot 0$ & $6 \cdot 6$ & $7 \cdot 0$ & $6 \cdot 6$ \\
\hline Fructose & $5 \cdot 3$ & $4 \cdot 8$ & $5 \cdot 0$ & $5 \cdot 0$ \\
\hline Glucose & $4 \cdot 9$ & $5 \cdot 1$ & $4 \cdot 9$ & $4 \cdot 8$ \\
\hline Mannose & $5 \cdot 1$ & 5.9 & $4 \cdot 9$ & $4 \cdot 8$ \\
\hline Galactose & $5 \cdot 0$ & $4 \cdot 8$ & $4 \cdot 8$ & $6 \cdot 2$ \\
\hline Sucrose & $5 \cdot 9$ & $5 \cdot 0$ & $6 \cdot 6$ & $6 \cdot 8$ \\
\hline Trehalose & $4 \cdot 8$ & $6 \cdot 6$ & $4 \cdot 8$ & $6 \cdot 5$ \\
\hline Maltose & $4 \cdot 8$ & $5 \cdot 0$ & $4 \cdot 9$ & $6 \cdot 6$ \\
\hline Cellobiose & $6 \cdot 8$ & $6 \cdot 6$ & $4 \cdot 8$ & $6 \cdot 4$ \\
\hline Melibiose & $4 \cdot 8$ & $6 \cdot 5$ & $4 \cdot 7$ & $6 \cdot 5$ \\
\hline Lactose & $4 \cdot 9$ & $6 \cdot 5$ & $4 \cdot 7$ & $6 \cdot 2$ \\
\hline Melezitose & $6 \cdot 9$ & $6 \cdot 6$ & $6 \cdot 9$ & $6 \cdot 5$ \\
\hline Raffinose & $4 \cdot 8$ & $6 \cdot 6$ & $4 \cdot 8$ & $6 \cdot 8$ \\
\hline Dextrin & $6 \cdot 5$ & $6 \cdot 5$ & $6 \cdot 5$ & $6 \cdot 7$ \\
\hline Starch & $7 \cdot 0$ & $6 \cdot 6$ & $7 \cdot 0$ & $6 \cdot 5$ \\
\hline Salicin & $5 \cdot 0$ & $6 \cdot 6$ & $6 \cdot 7$ & $6 \cdot 7$ \\
\hline No substrate & $7 \cdot 0$ & $6 \cdot 7$ & $7 \cdot 0$ & $6 \cdot 6$ \\
\hline
\end{tabular}

* Incubation was in anaerobic jars at $37^{\circ}$ for 2 weeks in a basal medium of $1 \%$ trypticase, $0.2 \% \mathrm{~K}_{2} \mathrm{HPO}_{4}, 0.01 \% \mathrm{MgSO}_{4} .7 \mathrm{H}_{2} \mathrm{O}$, and with $1 \%$ substrate. All substrates were sterilized by autoclaving in the basal medium except xylose, arabinose, maltose, cellobiose and melibiose which were sterilized by filtration. Significant fermentation is indicated by italic figures.

$\dagger$ Harrison (unpublished data).

+ Stevens (1956).

why lyophilized material appears to maintain its characters so well may be because the usual holding period (a few years) is relatively short as compared with the potential longevity of the suspension; thus the decreases in count may not have been great enough to bring about much selection. Storage at higher temperatures increases the death rate (Weiser \& Hennum, 1947; Proom \& Hemmons, 1949; Heckly, Anderson \& Rockenmacher, 1958; Heckly, Faunce \& Elberg, 1960), thus selection should occur more rapidly. However, changes in physiological traits of 
lactobacilli, including the anaerobic $L$. bifidus, streptococci, betacocci, and pediocoeci stored for 5 years at room temperature have not been encountered. Sharpe \& Wheater (1955) found little alteration of characters of lactobacilli lyophilized and stored for 6 months. On the other hand, with some unusuallylarge Bacteriodes spp., lyophilized and stored in an identical manner, pronounced alterations were observed.

Table 2 presents the fermentation spectrum of two strains of Bacteroides before lyophilization and after lyophilization and storage. Losses in the ability to ferment the polyhydric alcohols and di- and tri-saccharides have been sustained. Strain 28-30, in addition, had lost the ability to ferment galactose and, more surprising, had gained the ability to ferment glycerol. The end-products from glucose fermentation were not altered: for example, lactic acid remained the principal endproduct and the zinc lactate remained the laevorotatory isomer. Morphology, temperature requirements and gross growth characteristics also were unaltered. Quantitative viability studies were not made on these ampoules, but it is likely that great decreases in count had occurred, because after three additional years storage all ampoules had become sterile. A pleomorphic Bacteroides strain 29-9, also lyophilized, did not survive even the 5-year period. Thus, some Bacteroides appear much more sensitive to lyophilization than the lactic acid bacteria.

Table 3. Viability of bacteria after freezing as pellets

\begin{tabular}{|c|c|c|c|c|c|c|c|}
\hline \multirow[b]{2}{*}{ Species } & \multirow[b]{2}{*}{$\begin{array}{c}\text { Temp. } \\
\left({ }^{\circ}\right)\end{array}$} & \multirow[b]{2}{*}{$\begin{array}{l}\text { Initial } \\
\text { count }\end{array}$} & \multicolumn{5}{|c|}{ After storage for (weeks) } \\
\hline & & & 1 & 2 & 4 & 8 & 12 \\
\hline Escherichia coli & $\begin{array}{l}-25 \\
-60\end{array}$ & $\begin{array}{l}1.2 \times 10^{9} \\
1.2 \times 10^{9}\end{array}$ & $\begin{array}{l}1.1 \times 10^{9} \\
8.5 \times 10^{8}\end{array}$ & $\begin{array}{l}1.1 \times 10^{9} \\
1.0 \times 10^{9}\end{array}$ & $\begin{array}{l}8.7 \times 10^{8} \\
9.5 \times 10^{8}\end{array}$ & - & $\begin{array}{l}9.5 \times 10^{8} \\
9.4 \times 10^{8}\end{array}$ \\
\hline Vibrio costicolus & $\begin{array}{l}-25 \\
-60\end{array}$ & $\begin{array}{l}8.0 \times 10^{8} \\
8.0 \times 10^{8}\end{array}$ & $\begin{array}{l}1.1 \times 10^{9} \\
9.3 \times 10^{8}\end{array}$ & $\begin{array}{l}1.3 \times 10^{9} \\
5.6 \times 10^{8}\end{array}$ & $\begin{array}{l}1.3 \times 10^{9} \\
4.0 \times 10^{8}\end{array}$ & $\begin{array}{l}5.0 \times 10^{8} \\
4.0 \times 10^{7}\end{array}$ & $\begin{array}{l}3.6 \times 10^{8} \\
9.5 \times 10^{6}\end{array}$ \\
\hline Lactobacillus bifidus & $\begin{array}{l}-25 \\
-60\end{array}$ & $\begin{array}{l}1 \cdot 1 \times 10^{9} \\
1 \cdot 1 \times 10^{9}\end{array}$ & $\begin{array}{l}3.2 \times 10^{8} \\
9 \cdot 5 \times 10^{8}\end{array}$ & $\begin{array}{l}1.6 \times 10^{8} \\
9.8 \times 10^{8}\end{array}$ & $\begin{array}{l}8.8 \times 10^{7} \\
7 \cdot 7 \times 10^{8}\end{array}$ & $\begin{array}{l}5 \cdot 6 \times 10^{7} \\
9 \cdot 1 \times 10^{8}\end{array}$ & $\begin{array}{l}8.1 \times 10^{7} \\
1.1 \times 10^{9}\end{array}$ \\
\hline L. fermenti & $\begin{array}{l}-25 \\
-60\end{array}$ & $\begin{array}{l}4.3 \times 10^{8} \\
4.3 \times 10^{8}\end{array}$ & $\begin{array}{l}4.9 \times 10^{8} \\
7.8 \times 10^{8}\end{array}$ & $\begin{array}{l}2.1 \times 10^{8} \\
4.7 \times 10^{8}\end{array}$ & $\begin{array}{l}1.5 \times 10^{8} \\
4.4 \times 10^{8}\end{array}$ & $\begin{array}{l}1.2 \times 10^{8} \\
3 \cdot 4 \times 10^{8}\end{array}$ & $\begin{array}{l}8.5 \times 10^{7} \\
4.5 \times 10^{8}\end{array}$ \\
\hline Serratia marcescens & $\begin{array}{l}-25 \\
-60\end{array}$ & $\begin{array}{l}5.9 \times 10^{9} \\
5.9 \times 10^{9}\end{array}$ & $\begin{array}{l}5.7 \times 10^{9} \\
4.8 \times 10^{9}\end{array}$ & $\begin{array}{l}4.9 \times 10^{9} \\
3.6 \times 10^{9}\end{array}$ & $\begin{array}{l}6.1 \times 10^{9} \\
6.3 \times 10^{9}\end{array}$ & $\begin{array}{l}3.7 \times 10^{9} \\
3.7 \times 10^{9}\end{array}$ & $\begin{array}{l}4.4 \times 10^{9} \\
4.9 \times 10^{9}\end{array}$ \\
\hline
\end{tabular}

Frozen storage as pellets is suitable for some bacteria that are sensitive to lyophilization. Broth cultures are centrifuged, the broth decanted, and the centrifuge tubes containing the pellets placed directly in the deep-freeze unit. Results are presented in Table 3. Quantitative experiments have been undertaken with this method only over a 12-week period, but it is noteworthy that survivals may be better than with lyophilized material during this interval (Table 1). Storage as thick water suspensions may also be satisfactory, since many bacteria are not affected adversely thereby. For example, it has been observed repeatedly that Escherichia coli titres are not diminished as a result of freezing and thawing in distilled water (Harrison, 1956; Clement, 1961; Lion \& Bergmann, 1961).

Freezing agar slope and butt cultures at $-22^{\circ}$ gives good results and is convenient, but a quantitative viability study of this method has not been carried out. It is important that toxic end-products such as acid are minimized by using glucose concentrations in the medium of $\mathbf{0 . 2 5} \%$ or less. The following bacteria have been 
maintained frozen for 2-3 years with no detected changes in morphology, cultural characteristics, or physiological traits: 10 species of Streptococcus, including 14 strains of Streptococcus faecalis, 7 species of Bacillus, 6 species of Lactobacillus, 3 species of Acetobacter, 2 species of Microbacterium, 2 species of Propionibacterium, 2 species of Sarcina, 3 species of Betacoccus, 2 species of Micrococcus, Chromobacterium, Pediococcus, Proteus, Escherichia, Aerobacter, Alkaligenes, Pseudomonas and Saccharomyces. Anaerobic Bacteroides and Lactobacillus have been stored under aerobic conditions successfully for a year with no change in characters noted.

This research was initiated on Contract no. DA-18-064-CML-478 from the Chemical Corps Biological Laboratories, U.S. Army. Technical assistance was provided by $\mathbf{H}$. Lucille Kantzes and Gordon W. Wehrle. Later portions of the work were aided by grant E-1197 from the National Institute of Allergy and Infectious Diseases and Institutional Cancer Grant IN-25 from the American Cancer Society.

\section{REFERENCES}

Bunting, M. I. (1946). The inheritance of color in bacteria with special reference to Serratia marcescens. Cold Spr. Harb. Symp. quant. Biol. 11, 25.

Clement, M. T. (1961). Effects of freezing, freeze-drying, and storage in the freeze-dried and frozen state on viability of Escherichia coli cells. Canad. J. Microbiol. 7, 99.

Harrison, A. P., Jun. (1949). Master's thesis. University of Maryland, College Park.

Harrison, A. P., Jun. (1956). Causes of death of bacteria in frozen suspensions. Antonie van Leeurvenhoek. J. Serol. Microbiol. 22, 407.

Harrison, A. P., Jun. \& Hansen, P. A. (1954). Characterization of the Lactobacteriaceae encountered as secondary invaders in blackhead liver lesions of turkeys. Z Zbl. Bakt., I Orig. 161, 125.

Heckiy, R. J., Anderson, A. W. \& Rockenmacher, M. (1958). Lyophilization of Pasteurella pestis. Appl. Microbiol. 6, 255.

Heckiy, R. J., Faunce, K., Jun. \& Elberg, S. S. (1960). Lyophilization of Brucella melitensis. Appl. Microbiol. 8, 52.

Kögl, R. \& Postowsky, J. J. (1930). Über das grüne Stoffwechselprodukt des Bacillus chlororaphis. Ann. Chem. 480, 280.

Lion, M. B. \& Bergmann, E. D. (1961). The effect of oxygen on freeze-dried Escherichia coli. J. gen. Microbiol. 24, 191.

Proom, H. \& Hemmons, L. M. (1949). The drying and preservation of bacterial cultures. J. gen. Microbiol. 3, 7.

Rhodes, M. \& Fisher, P. J. (1950). Viability of dried bacterial cultures. J. gen. Microbiol. 4,450 .

Sharpe, E. \& Wheater, D. M. (1955). The physiological and serological characters of freeze-dried lactobacilli. J. gen. Microbiol. $12,513$.

StaMP, L. (1947). The preservation of bacteria by drying. J. gen. Microbiol. 1, 251.

Stevens, W. C. (1956). Taxonomic studies on the genus Bacteroides and similar forms. Dissertation. Vanderbilt University, Nashville.

Weiser, R. S. \& Hennum, L. A. (1947). Studies on the death of bacteria by drying. $J$. Bact. 54, 17 (abstract). 